Acta Universitatis Wratislaviensis • No 3772

Literatura i Kultura Popularna XXII, Wrocław 2016

DOI: $10.19195 / 0867-7441.22 .6$

\title{
Kamila Augustyn
}

Uniwersytet Wrocławski

\section{Legenda o (nie)świętym Wroclawiu Lukasza Orbitowskiego}

\section{Słowa kluczowe: Wrocław, horror, literatura fantastyczna, place studies, neo-noir}

Keywords: Wroclaw, horror story, fantastic literature, place studies, neo-noir

Literackie reprezentacje miast przybierają różne postacie: od jak najbardziej realnych, mimetycznych, topograficznie naśladowczych po wyobrażeniowe, formy mentalnej reprezentacji świata, projekcje stanu duszy głównego bohatera czy teoretyczne konstrukty rzeczywistości. Analiza sposobu obrazowania miejskiej przestrzeni w powieści fantastycznej Łukasza Orbitowskiego Święty Wrocław (2009) ma na celu określenie roli miasta w utworze utrzymanym w stylistyce horroru, a przy tym ukazanie gry autora $\mathrm{z}$ literacką tradycją i konwencją $\mathrm{w}$ ramach popkulturowego dyskursu. Literaturoznawcza egzegeza powieści w kontekstach socjokulturowym oraz gatunkowym stanowi przyczynek do szerszych badań nad językowym obrazem świata i kategorią miejsca w literaturze (place studies), prowadzonych metodami ilościowo-jakościowymi ${ }^{1}$. W obszar geograficzny podjętych studiów nad wizerunkiem miasta, a dokładniej Wrocławia, wpisuje się także, stanowiący kontrapunkt dla niniejszego wywodu, „wrocławski cykl” powieści kryminalnych autorstwa Marka Krajewskiego.

W kryminałach retro $\mathrm{z}$ Breslau $\mathrm{w}$ tytule ${ }^{2}$ topografia miasta zostaje przez autora odtworzona bardzo skrupulatnie. Służy to tyle osadzeniu akcji w ukonkretnionej przestrzeni, ile spotęgowaniu poczucia zagubienia czytelnika wśród obcobrzmiących nazw ulic i obiektów — w kontekście gatunkowym tak bardzo

${ }^{1}$ Analizowane są m.in. opisujące miasto leksemy, tak pod względem nacechowania emocjonalnego (pozytywne, negatywne, neutralne), jak typu odniesienia — realne (przedmiotowe, materialne) bądź abstrakcyjno-relacyjne (symboliczne).

2 M. Krajewski, Śmierć w Breslau, Wrocław 1999; idem, Koniec świata w Breslau, Warszawa 2003; idem, Widma w mieście Breslau, Warszawa 2005; idem, Festung Breslau, Warszawa 2006; idem, Dżuma w Breslau, Warszawa 2007; idem, Rzeki Hadesu, Kraków 2012. 
przecież pożądanego ${ }^{3}$. Jednocześnie, mimo kartograficznej wręcz dokładności autora, obraz miasta wydaje się mocno odrealniony. To efekt kreowania Breslau lat 20. i 30. ubiegłego wieku na miasto grzechu znane z powieści nurtu neo-noir, kryminałów Raymonda Chandlera ${ }^{4}$ i filmów takich, jak Harry Angel (reż. A. Parker, USA-Kanada-Wielka Brytania 1987) czy Sin City. Miasto grzechu (Sin City, reż. R. Rodriguez, USA 2005), którymi inspirował się Krajewski ${ }^{5}$. Taką kreację przestrzeni niewątpliwie wspomaga zastosowana przez autora powieści technika światłocienia. Przy jej użyciu możliwe jest kontrastowanie postaw bohaterów nie zawsze jednoznacznie dobrych albo złych - a w ten sposób także kształtowanie atmosfery miasta jako scenerii czy nawet sceny, światłocień bowiem silnie teatralizuje tak ruchy, jak przestrzeń — dość brutalnej i nieuczciwej gry, jaką prowadzą poszczególne postacie.

Powstały w ten sposób obraz miasta, choć topograficznie bez zarzutu, bo zbudowany na podstawie map starego Breslau, odnalezionych przez Krajewskiego we wrocławskich archiwach, można jednak uznać za mocno spreparowany. Taką tezę wysuwa m.in. Anna Gemra w artykule Eberhard Mock na tropie: Breslau/ Wroctaw w powieściach Marka Krajewskiego, zwracając uwagę na to, że główną rolę w kreowaniu wizerunku tego „hitlerowskiego miasta” pełnią w całym cyklu nie tyle opisy Breslau, jego architektury i mieszkańców, ile enumeracje niemieckojęzycznych nazw samego miasta, jego ulic i budynków, jak również okładkowe recenzje kolejnych powieści, przywołujące znane z licznych filmów, dość stereotypowe wyobrażenia przedwojennych, niemieckich metropolii ${ }^{6}$.

Swoista mistyfikacja wizerunku Wrocławia dokonuje się również w horror story Orbitowskiego. Mimo iż akcja powieści jest osadzona w realnej przestrzeni, weryfikowalnej za pomocą kilkudziesięciu wzmiankowanych w tekście nazw topograficznych: najbardziej reprezentacyjnych ulic, arterii komunikacyjnych i punktów miasta (ulice: Świdnicka, Żmigrodzka, Obornicka, Powstańców Ślą-

${ }^{3} \mathrm{~W}$ analizowanych powieściach ,wrocławskiego cyklu” Marka Krajewskiego pojawia się ogółem 914 nazw topograficznych (ulic, placów, mostów, budynków, parków Wrocławia): w Śmierci w Breslau 147, w Końcu świata w Breslau 347, w Widmach w mieście Breslau 101, w Festung Breslau 120, w Dżumie w Breslau 124 i w Rzekach Hadesu 75. Na podstawie badań własnych.

${ }^{4}$ Zob. R. Chandler, Żegnaj laleczko (Farewell, my Lovely, 1940; wyd. pol. 1969); idem, Dtugie pożegnanie (The Long good-bye, wyd. pol. 1979); J. Ellroy, Czarna Dalia (The Black Dahlia, 1987; wyd. pol. 1998); idem, Tajemnice Los Angeles (L.A. Confidential, 1990; wyd. pol. 1998). Zob. też M. Kempna-Pieniążek, Polskie adaptacje estetyki noir i neo-noir — rekonesans historyczny, „Biblioteka Postscriptum Polonistycznego” 2015, nr 5, http://www.postscriptum.us.edu.pl/pdf/ bps2015_5_14.pdf, dostęp: 4.06.2016.

5 Zob. Poprawki w mundurze esesmana. Z Markiem Krajewskim rozmawiat Wojciech Orliński, www.wysokieobcasy.pl/wysokie-obcasy/1,53581,4950784.html, dostęp: 25.02.2011; por. Po piętnastej. Marek Krajewski opowiada Stanisławowi Łubieńskiemu o fascynacji Breslau i o tym, co taczy prace filologa i detektywa, „Lampa” 2006, nr 2.

${ }^{6}$ A. Gemra, Eberhard Mock na tropie: Breslau/Wroctaw w powieściach Marka Krajewskiego, http://www.ifp.uni.wroc.pl/data/files/pub-8638.pdf, s. 141, dostęp: 30.03.2015, a także w: Ślaskie pogranicza kultur, red. M. Ursel, O. Taranek-Wolańska, t. 2, Wrocław 2012, s. 119-143. 
skich; most Osobowicki; Dworzec Główny PKP), znanych miejsc i zabytków (Rynek, Stare Miasto, Ostrów Tumski), centralnie usytuowanych lokali rozrywkowych (kluby „Jazzda” i „Novocaina”), a także punktów na mapie miasta dających się zidentyfikować jedynie mieszkańcom Wrocławia (najlepszy ogólniak, bar mleczny na Nowym Świecie, Galeria Dominikańska, Ogród Japoński, Pracownicze Ogródki Działkowe „Różanka”) czy mniej znanych, bo peryferyjnych ulic (Bałtycka, Broniewskiego, Kamieńskiego) albo bliżej nieokreślonych topograficznie obiektów (poczta, nasyp kolejowy, zakład energetyczny, gazownia, sklepik z ciuchami), obraz miasta nie ma charakteru mimetycznego ${ }^{7}$. Rzeczywista topografia to drugi, „świecki” plan utworu. Pierwszym jest tajemnicze osiedle Polanka, stanowiące centralny, z punktu widzenia fabuły, punkt miasta, wokół którego narasta atmosfera dziwności i niesamowitości. To ziejące czarną materią i pochłaniające każdego, kto się do niego zbliży, wrocławskie osiedle przywołuje na myśl tajemnicze, średniowieczne zamczysko ${ }^{8}$, znane z odmiany powieści grozy o gotyckim rodowodzie ${ }^{9}$. Utwór Orbitowskiego można by uznać za jej uwspółcześnioną wersję.

„Święty Wrocław” funkcjonuje w powieści jako społeczno-kulturowy konstrukt współczesności ${ }^{10}$. Służy on autorowi do krytyki: fanatyzmu religijnego — stąd wyobrażenie miasta jako ,świętego" i oddająca to biblijna metaforyka - a także koniunkturalizmu i konsumpcjonizmu, które uwidocznione zostały w postawach bohaterów oraz relacjonujących rozgrywające się wydarzenia mediów ${ }^{11}$. Narrator podsuwa czytelnikowi różne odpowiedzi na pytanie, czym jest lub może być „Święty Wrocław”: „efektem wielkiego klerykalnego spisku”, „projekcją podświadomości zbiorowej”, „pierwszym znakiem nadchodzącej zagłady”, „pozostałością architektoniczną Obcych”, „wielkim pojazdem z kosmosu”, „kawałem”, „zajebistym wykurwem”, „wiecznym schronieniem dla ocalałych”. I choć to w gestii czytelnika zdaje się pozostawać ostateczna interpretacja, góru-

7 Miejską przestrzeń buduje autor za pomocą wzmiankowania nazw 50 ulic i obiektów. Wyliczenia pochodzą z badań własnych. Załącznik w postaci Zestawienia nazw topograficznych w powieści ,Święty Wrocław” znajduje się na końcu artykułu.

${ }^{8}$ Motywy tajemniczego miasta, czy raczej miasteczka (Rykusmyku), przyciągającego z niezwykłą siłą oraz średniowiecznego zamku wykorzystuje Orbitowski także w powieści Szczęśliwa ziemia, Kraków 2013.

${ }^{9}$ O niespójności nazewniczej w odniesieniu do współczesnej literatury grozy czytaj więcej m.in. w: Droga do science fiction. Od Wellsa do Heinleina, wybór, przedmowa i tło historyczne J. Gunn, t. 2, Warszawa 1986, s. 132, a także u D. Zając, Gatunek w próżni: Amerykańska powieść grozy po 1835 r., „Studia Litteraria Universitatis Iagellonicae Cracoviensis” 2009, nr 4, s. 159-162.

10 B. Trocha, Literatura popularna w perspektywie badawczej. Rozważania metodologiczne, [w:] J.Z. Lichański, W. Kajtoch, B. Trocha, Literatura i kultura popularna. Metody: propozycje i dyskusje, Wrocław 2015, s. 80.

11 O zniekształceniach obrazu w przekazie medialnym czytaj w: R. Kapuściński, Autoportret reportera, Kraków 2003, s. 116-124. 
jący nad innymi postaciami narrator ${ }^{12}$ - jak się bowiem okazuje, jest on jednym z bohaterów utworu - narzuca swoją optykę dostatecznie wyraźnie, głównie za pomocą prześmiewczego, stylizowanego na biblijny języka oraz kreacji postaci: męczenników poświęcających się dla sprawy, wyznawców i pielgrzymów, aby czytelnik mógł pojąć przenośnię, jaką posłużył się Orbitowski. Wyraźnie narzucającą się interpretację powieści w duchu biblijnym wspiera przedstawienie miasta na wzór figury Chrystusa za pomocą takich biologicznych metafor służących do opisu miejskiej topografii, jak: „starcie u stóp Świętego Wrocławia”, „serce miasta” i „ręce Świętego Wrocławia”, które nieprzypadkowo kojarzą się z figurą ukrzyżowanego Chrystusa i kultem Jego Najświętszego Serca. „Święty Wrocław" nosi w sobie jednak pewną ambiwalencję, która wskazuje na grę autora $\mathrm{z}$ konwencją. Jest bowiem miasto w kreacji Orbitowskiego jednocześnie przestrzenią sakralną i piekielną. To mroczne sacrum, które emanuje tajemniczym ciepłem, hipnotyzuje mieszkańców Wrocławia i z taką samą siłą przyciąga tysiące pielgrzymów z całej Polski. Wielka bitwa o „Święty Wrocław”, jaka rozgrywa się W zakończeniu powieści, to efekt tej zbiorowej psychozy, ale też „cud awantury” - symboliczne odkupienie, po którym „deszczowe chmury, wiszące nad Wrocławiem od wielu tygodni" wreszcie się rozwiewają ${ }^{13}$. Schematy stylistyczne i fabularne rodem z Biblii funkcjonują w powieści jako intertekstualne zapożyczenia w funkcji parodystycznej, rozumianej jako odmiana stylizacji stawiająca sobie za cel nie tyle komiczne, ile krytyczne naśladowanie ${ }^{14}$. Jednocześnie wiele wskazuje na to, że biblijność Świętego Wrocławia to jedynie (pop)kulturowy kostium. Zasadniczy wpływ na kreację przestrzeni ma bowiem szeroko rozumiana, nie tylko w aspekcie religijnym, ale także ekonomicznym i psychologicznym, w kategoriach ogólnokrajowych, a nie tylko lokalnych — sytuacja społeczna.

Sposób obrazowania miasta przez powieściowego narratora za pomocą biblijnych metafor, porównań i analogii można interpretować, jak wiele utworów z gatunku horror story, także w duchu Freudowskiej psychoanalizy, uznając go za próbę wytłumaczenia fenomenu religii psychologią tłumu. W powieści Orbitowskiego wyparte, tzn. nieakceptowalne, w związku z czym odsuwane w głąb psychiki, treści, popędy i emocje ${ }^{15}$ przyjmują formę miasta wyobrażonego jako osobny byt ${ }^{16}$. Do jego ukonstytuowania i uprawdopodobnienia służą autorowi realne odniesienia (topograficzne — do ulic, kierunków; osobowe — do ludzi; architek-

12 Więcej o roli narratora w powieściach typu horror story w: S. Stewart, The epistemology of the horror story, „The Journal of American Folklore” 95, 1982, nr 375.

13 Ł. Orbitowski, Święty Wrocław, Kraków 2009, s. 269.

14 Zob. R. Nycz, Parodia i pastisz. Z dziejów pojęć artystycznych w świadomości literackiej XX wieku, [w:] idem, Tekstowy świat. Poststrukturalizm a wiedza o literaturze, Warszawa 2000, s. 200-205.

15 Zob. Z. Freud, Nieświadomość, [w:] Z. Rosińska, Freud, Warszawa 2002, s. 193; J. Przybyła, Zygmunta Freuda koncepcja nieświadomego, „Psychoterapia” 2009, nr 2 (149), s. 21-22.

16 A. Tudor, Why horror? The peculiar pleasures of a popular genre, „Cultural Studies” 11, 1997, nr 3, s. 443-463. 
toniczne - do obiektów) budujące sferę profanum i stanowiące 57\% wszystkich określeń ${ }^{17}$ Wrocławia pojawiających się w utworze ${ }^{18}$, a także osadzający akcję we współczesności komentarz narratora, wzorowany miejscami na sposobie zdawania relacji przez goniące za tanią sensacją mass media. Fantastyczną, pierwszoplanową sferę utworu tworzą w warstwach językowo-brzmieniowej i znaczeniowej: abstrakcyjne, głównie personifikujące i metaforyczne określenia miasta pochodzące ze sfer biblijnej, biologicznej, militarnej oraz filozoficzno-psychologicznej, których udział w obrazowaniu przestrzeni wynosi $43 \%$, a w warstwie wyglądów ${ }^{19}$ - kreowana przez autora, choć nie bez ironicznego dystansu, aura cudowności i niesamowitości, przejęta przez fantastykę z baśni ${ }^{20}$.

Rosnące w oczach tajemnicze osiedle Polanka kanonizowane przez twórcę na tytułowy „Święty Wrocław”, zanim jeszcze rzekomo dokonane przez niego cuda zostaną uznane i potwierdzone ${ }^{21}$, jest przestrzenią sytuującą się na granicy dobra i zła, doczesności i wieczności. Swym niepewnym statusem budzi więc zrozumiały niepokój, ale też zachwyt, u niektórych natomiast wywołuje irytację. Mimo czarnej aury, jaka otacza miasto, zyskuje ono cechy miejsca kultu porównywalnego do Częstochowy. Tymczasem to nic innego jak upiorna karykatura religii, wiary w odrodzenie i życie wieczne po śmierci, a także, jak dowodzi litania do „Świętego Wrocławia", wyśpiewywana przez krążących wokół osiedla pielgrzymów, wiary w zbawienie dokonane nie przez Boskiego Syna, lecz miasto, które pozuje w utworze na samego Boga ${ }^{22}$. Jeśliby wziąć to uosobienie przestrzeni za rodzaj uwznioślenia, podobnie jak uwzniośleniem człowieka było przybranie jego postaci przez Boskiego Syna, należałoby wówczas stwierdzić, że Wrocław odgrywa w powieści Orbitowskiego rolę szczególną, jest bowiem centralną osią wydarzeń — swoistą axis mundi. Czy jednak czyni to ze Świętego Wroctawia powieść fundacyjną nadodrzańskiego grodu? Nie. Podobnie jak fundacyjnym nie jest żaden z kryminałów Krajewskiego. Po pierwsze, nie oddaje on specyfiki miasta i jego społeczeństwa, wszak do tego celu nie wystarczy kilkadziesiąt czy nawet kilkaset nazw topograficznych, wzmiankowanych w całym utworze, a po drugie, nie legitymizuje kon-

${ }^{17}$ Określenia rozumiane jako epitety, zwroty i wyrażenia użyte do opisu miasta $\mathrm{w}$ danym kontekście.

18 Na podstawie własnych badań leksemów określających Wrocław w powieści Orbitowskiego.

19 R. Ingarden, O dziele literackim: badania z pogranicza ontologii, teorii języka i filozofii literatury, przeł. M. Turowicz, Warszawa 1988.

20 A. Smuszkiewicz, Zaczarowana gra. Zarys dziejów polskiej fantastyki naukowej, Poznań 1982, s. 12; R. Handke, Polska proza fantastyczno-naukowa. Problemy poetyki, Wrocław-Warszawa-Kraków 1969, s. 6-7.

21 Tytuły ośmiu rozdziałów powieści prowadzących do Świętego Wrocławia (tak brzmi tytuł rozdziału 9) to: Cud narodzin, Cud spotkań, Cud dla Firgaty, Cud przemienienia, Cud okrucieństwa, Cud poszukiwań, Cud dla Nieszczęsnej, Cud Awantury. Zob. Ł. Orbitowski, Święty Wroctaw..., s. 297.

22 Ibidem, s. 249, 251. 
strukcji przeszłości²3. Autor Świętego Wrocławia nie rekonstruuje historii Breslau/ Wrocławia, ani też nie odwołuje się do losów dawnych mieszkańców miasta. Dopisuje jednak kolejne, jeszcze bardziej fantastyczne, tworząc tym samym nową legendę wcale nie tak świętego, jak można by sądzić po tytule, Wrocławia.

Powieść niewątpliwie zwraca uwagę umiejętnym przekształceniem realnej rzeczywistości w realność fantastycznej opowieści ${ }^{24}$. Tę jej wartość oddają także przywołane już dane liczbowe dotyczące obrazowania miasta za pomocą abstrakcyjnych określników, mających stosunkowo duży udział w opisie miejskiej przestrzeni ${ }^{25}$. Sfera metaforycznych odwołań wskazuje na to, że pisarz nie stwarza rzeczywistości na wzór baśniowej, ale sakralnej, przy czym miejsce święte, jakie uobecnia w powieści Orbitowskiego Wrocław, ma nie tylko religijne konotacje. Zgodnie z koncepcją Mircei Eliadego może być to bowiem kompleks pojmowany w sensie architektonicznym, ale też biologicznym, składający się zatem z elementów roślinnych/przyrodniczych (aura), zwierzęcych (zwierzęcy towarzysze narratora: Pies, Ptak i Dzik), ludzi, a więc osób działających (bohaterów), kultywowanych przez nich obrzędów oraz doznawanych wrażeń i przeżywanych emocji ${ }^{26}$.

Sakralny wizerunek Wrocławia budują liczne jego personifikacje oraz postulaty głoszone przez przybyłych do miasta pielgrzymów, w dalszej zaś kolejności świeckie wyobrażenia i interpretacje tego, czym jest „Święty Wrocław” i na czym polega jego fenomen, powtórzone przez narratora za mediami lub bohaterami powieści. Wtargnięcie sfery sacrum — „Świętego Wrocławia”, w sferę profanum — rzeczywistość współczesnej metropolii i tak ostra konfrontacja obu sfer przynosi efekt iście groteskowy. W wielu wypadkach trudno $\mathrm{z}$ tego powodu jednoznacznie określić nacechowanie zwrotów, fraz oraz wyrażeń, za pomocą których autor opisuje Wrocław, ponieważ wywołują one w tak zarysowanym kontekście i przy świadomości pozorowania obiektywnej kronikarskiej narracji zupełnie sprzeczne uczucia. Przejaskrawiony opis przestrzeni, już od samego początku kreowanej na mroczną i tajemniczą, skłania do postrzegania miasta w kontekście negatywnym. „Narodzin Świętego Wrocławia” nie zwiastuje gwiazda, lecz nadciągające deszczowe chmury. Pozbawione słonecznego światła miasto przygasa,

${ }^{23}$ Zob. A. Zawada, Temat Wrocław, [w:] Literatura, kultura, komunikacja. Księga pamiatkowa ku czci profesora Jerzego Jarzębskiego w 60. rocznicę urodzin, red. K. Stasiuk, M. Graszewicz, Wrocław 2006, oraz H. Orłowski, Za górami, za lasami... O niemieckiej literaturze Prus Wschodnich 1863-1945, Olsztyn 2003, s. 54.

24 A. Cieński, Pejzaż Wrocław, „Pomosty” 2003, nr 8, s. 193.

25 Co ciekawe, równie wysoki, bo około- lub nawet ponadczterdziestoprocentowy udział leksemów o charakterze symbolicznym w opisie miasta występuje w większości powieści Marka Krajewskiego z Breslau w tytule: w Końcu świata w Breslau abstrakcyjne określniki miasta stanowią 38\%, w Śmierci w Breslau 40\%, w Widmach w mieście Breslau 42\%, w Festung Breslau 44\%, a w Dżumie w Breslau aż 47\%. Jest to bezpośrednio związane z kreowaniem miasta na wzór osobowości głównego bohatera.

26 Zob. M. Eliade, Traktat o historii religii, przeł. J. Wierusz-Kowalski, Warszawa 2000, s. $389-408$. 
szarzeje, a wraz z nim także i zamieszkujący je ludzie. Wrocław staje więc na krawędzi załamania, podobnie jak upadająca twierdza Breslau z powieści Krajewskiego. Miasto „potrzebuje znaku, odmiany” i odmianę tę ma przynieść właśnie tajemniczy „Święty Wrocław”. Mimo iż czarne i ciche osiedle z wielkiej płyty nie napawa optymizmem, to właśnie ono - przekonuje narrator głosami bohaterów - przyniesie ocalenie, czego ma dowieść apokaliptyczne zakończenie utworu:

Płomień pędził przez Wrocław, tężał, pozostawiając za sobą ziemię jałową i gorącą: resztki ulic i ludzi żarzyły się niczym lawa. Dalej, przez Brzeg, Oławę, Legnicę, Polskę i świat, zostawiał za sobą płonące groby. Nic nie mogło zatrzymać tej złotej fali, słońce wędrowało ku górze, świecąc mocniej, dzieląc się swoją siłą. Zawrzały jeziora, morza, rzeki, Tatry i Alpy pokłoniły się przed ogniem. Krzyk poniósł się pod niebo i zaraz umilkł, nie dotarł do Świętego Wrocławia. Ten stał niewzruszony i mocny, wieczne schronienie dla ocalałych, niech płomień pędzi i przepala, tu będzie, tu jest bezpiecznie ${ }^{27}$.

Wizja Wrocławia, kształtowana przez Orbitowskiego na wzór tej z Apokalipsy św. Jana, mimo całej swojej makabryczności, nie może być więc postrzegana jako wyłącznie negatywna, choć dane liczbowe pochodzące z analizy określających miasto leksemów potwierdzają pejoratywny obraz miasta (147 negatywnych jego określeń do 74 pozytywnych i 79 neutralnych) ${ }^{28}$. Zakończenie powieści zmienia to nastawienie, co zasadniczo odróżnia kreowaną przez Orbitowskiego wizję miasta-świata od tej, jaką przynosi cykl powieści kryminalnych typu hardboiled autorstwa Krajewskiego. Po raz kolejny dowodzi również gry autora Świętego Wrocławia z literackimi konwencjami.

Obie powieści różni także osoba narratora, dość typowego we „wrocławskim cyklu", i tajemniczego, łączącego sfery sacrum i profanum w Świętym Wrocławiu, gdzie poznajemy go najpierw jako kronikarza, który próbuje spisać losy „Świętego Wrocławia”, rzekomo dysponując jedynie „urywkami historii, wspomnień" 29 oraz słowami otaczających go kalekich zwierząt — symbolicznych karykatur ewangelistów: jednookiego Psa, uznającego Wrocław za zwyczajne miasto, a jego mieszkańców za ludzi, których ogarnęło zbiorowe szaleństwo; jednoskrzydłego Ptaka, który jest przekonany o wniebowzięciu miasta i wierzy w ocalenie jego mieszkańców, a także Dzika o jednym kle, dla którego bitwa o „Święty Wrocław” jest walką dobra ze złem, która zakończy się ostateczną przegraną zła utożsamianego z Szatanem.

Nie pisałbym, gdybym znalazł inne zajęcie lub lepsze towarzystwo. Trudno rozmawiać tylko ze zwierzętami i pozostać przy zdrowych zmysłach. Nawet nie wiem, która jest godzina. Nie odróżniam nieba od ziemi — być może zwisam z gwiazdy głową w dół. Czasem śnię, że się obudziłem. Opisuję Święty Wrocław jako rozmowę z samym sobą ${ }^{30}$

27 Ł. Orbitowski, Święty Wrocław..., s. 294-295.

28 Na podstawie badań własnych.

29 Ibidem, s. 6.

30 Ibidem. 
— przyznaje narrator już na drugiej stronie powieści. Z kolejnych dowiadujemy się, że był nie tylko świadkiem, ale i uczestnikiem opisywanych wydarzeń. Jego pozorowana na obiektywną, pseudokronikarska narracja jest więc $\mathrm{w}$ istocie całkiem subiektywna, o czym przekonują w dalszej części utworu coraz bardziej dosadne, ironiczne komentarze, za pomocą których narrator ośmiesza i dyskredytuje tak władze (miejskie, państwowe), jak samo społeczeństwo ${ }^{31}$.

Próbując wytłumaczyć, na czym polega fenomen „Świętego Wrocławia”, narrator-rewelator prawdy o mieście wciela się w rolę psychologa, diagnozującego problemy każdej z grup ludności, których reprezentanci stali się bohaterami snutej przez niego opowieści. Dla tej części miejskiej populacji, która nie jest oddana religijnemu fanatyzmowi, „Święty Wrocław” to nie miejsce święte, które istnieje poza czasem, ani też miejsce mocne czy niewzruszone, lecz po prostu kolejne oszustwo. Wielu wrocławian traktuje je jako kolejną atrakcję turystyczną, na której można nieźle zarobić, umiejętnie wykorzystując nadarzającą się ku temu okazję. Oddając głos postaciom i nagłaśniającym sprawę mediom, narrator nie ucieka od oceny postępowania bohaterów. Jest np. bardzo krytyczny wobec komendanta Roberta Janusza Cegły, o którym pisze z nieskrywaną niechęcią: „Poznałem go kiedyś i sprawiał na mnie wrażenie człowieka, który zjadłby własną matkę w zamian za nową gwiazdkę przy dystynkcjach"32. Łamiąc kronikarską rzetelność, snujący opowieść o „Świętym Wrocławiu” zwierza się też czytelnikowi ze swoich uczuć, odwołuje do rzekomo wspólnych doświadczeń, zdradza swoje przemyślenia, które dotyczą zarówno własnej kondycji psychofizycznej, jak i procesu pisania.

Dwudzielna konstrukcja świata przedstawionego utworu, w którego „,pozornie realistycznym uniwersum" dochodzi do konfrontacji realnego $\mathrm{z}$ fantastycznym (wyobrażonym $)^{33}$, służy nadrzędnemu celowi powieści, jakim jest demaskatorstwo. Do tego celu Orbitowski używa figury miasta. Za pomocą fantastyczno-biblijnego kostiumu, w jaki przyobleka Wrocław, pisarz obnaża wszystkie grzechy współczesności, co upodabnia powieść do utworów nurtu noir, takim go jednak nie czyni. W nieraz nachalnie parabolicznej wymowie i prześmiewczym, nieco żartobliwym tonie powieści, a także wypowiedziach narratora na temat społeczeństwa widać tradycje krytycznego oglądu świata nawiązujące, choć nie wprost, do tradycji oświeceniowej powiastki filozoficznej; w samym zaś Orbitowskim, któ-

31 Oto przykład takiego komentarza, w którym narrator ujawnia, by nie rzec, manifestuje, swoją wszechwiedzę: „Gdy ludzie się kochają, świat spowalnia, wydarzenia pędzą naprzód, a tych dwoje nie martwi się nic a nic, widzę ich wyraźnie w każdym momencie. Znam ich wątpliwości. Każdą myśl, każdy gest, i na przekór sobie jestem znudzony do wyrzygania. Mdli mnie i zachwyca na przemian, aż jedno z drugim miesza się zupełnie”. Ibidem, s. 129.

32 Ibidem, s. 100.

33 W. Kajtoch, Jak badać literature popularną? Kolejna odpowiedź, [w:] J.Z. Lichański, W. Kajtoch, B. Trocha, op. cit., s. 51. 
ry, skrywając się za narratorem-kronikarzem, wytyka cały ten „wrocławski” w szerszym kontekście także ,polski” — „syf”, można upatrywać spadkobiercy autora Kandyda.

\begin{tabular}{|c|l|}
\hline \multicolumn{2}{|c|}{ Zestawienie nazw topograficznych w powieści Święty Wroclaw } \\
\hline 1. & bar mleczny na Nowym Świecie \\
\hline 2. & biuro tłumaczeń przy ul. Świdnickiej \\
\hline 3. & Dom Działkowca \\
\hline 4. & Dworzec Główny PKP \\
\hline 5. & Galeria Dominikańska \\
\hline 6. & gazownia \\
\hline 7. & jadłodajnia \\
\hline 8. & Janówek \\
\hline 9. & klub „Jazzda” \\
\hline 10. & Komenda Wojewódzka Policji \\
\hline 11. & Krzyki \\
\hline 12. & Lewiatan \\
\hline 13. & most Osobowicki \\
\hline 14. & najlepszy ogólniak \\
\hline 15. & nasyp kolejowy \\
\hline 16. & klub „Novocaina” \\
\hline 17. & Nowy Świat \\
\hline 18. & oczyszczalnia ścieków na Janówku \\
\hline 19. & Ogród Japoński \\
\hline 20. & osiedle przy ul. Broniewskiego \\
\hline 21. & osiedle przy ul. Żmigrodzkiej \\
\hline 22. & Ostrów Tumski \\
\hline 23. & pl. Solny \\
\hline 24. & poczta \\
\hline 25. & Polanka \\
\hline 26. & Poltegor \\
\hline 27. & Pracownicze Ogródki Działkowe „Róa \\
\hline
\end{tabular}




\begin{tabular}{|l|l|}
\hline 28. & Pręgierz \\
\hline 29. & Promenada Staromiejska \\
\hline 30. & Psie Pole \\
\hline 31. & restauracja ,Rodeo” \\
\hline 32. & Różanka \\
\hline 33. & Rynek \\
\hline 34. & sex shop \\
\hline 35. & sklepik z ciuchami \\
\hline 36. & stadion \\
\hline 37. & Stare Miasto \\
\hline 38. & ul. Bałtycka \\
\hline 39. & ul. Broniewskiego \\
\hline 40. & ul. Kamieńskiego \\
\hline 41. & ul. Kochanowskiego \\
\hline 42. & ul. Obornicka \\
\hline 43. & ul. Powstańców Śląskich \\
\hline 44. & ul. Świdnicka \\
\hline 45. & ul. Zawalna \\
\hline 46. & ul. Żmigrodzka \\
\hline 47. & Wały Karłowickie \\
\hline 48. & wieża ciśnień \\
\hline 49. & zakład energetyczny \\
\hline 50. & Zoo \\
\hline
\end{tabular}

\section{Legend of (Not)Holy Wrocław by Lukasz Orbitowski}

\section{Summary}

This article aims to show how Luke Orbitowski shapes the image of the city in his novel Święty Wroctaw ("Holy Wroclaw"). Analysis of tokens that build the image of the city, their meaning, the way of reference (abstract or real) and a striking emotional impression allows the reader to specify the function of the city, and answer the question about what differs presented visions of Wroclaw in the horror story novel by Orbitowski and the crime drama in the style of noir by Marek Krajewski. 